\title{
Şâhî Divanı'nın İki Yeni Yazma Nüshası
}

\section{Üzeyir ASLAN ${ }^{1}$}

\author{
Öz
}

\begin{abstract}
Mesud Mirza, 15. yy. Orta Asya şairlerindendir. Babası Sultan Mahmud Mirza (öl. 901/1495), dedesi ise Ebu Said Mirza (öl. 874/1469)'dır. Mesud Mirza’nın soyu Timur (öl. 808/1405)'a dayanır. Türkçe şiirlerinde "Şāhī”, Farsça şiirlerinde 'Ārifi”" mahlasını kullanan şairin Farsça dîvânı bugüne kadar tespit edilememiştir. Türkçe dîvânının ise İngiltere nüshaları daha önce J. Eckmann tarafından tanıtılmıştır. İndia Office Kitaplığında Turki Ms 23 ve 25 numarada bulunan bu iki nüsha esas alınarak dîvân yayını T. Mirzaev (2001) ve M. Tekcan (2005) tarafından yapılmıştır. Anılan nüshalardan başka Mesud Mirza Şâhî Dîvânı'nın iki yeni nüshası daha tespit edilmiştir. Bunlar; İran Kitabhane-yi Devlet-i Aliyye 2205 (İ) ve Bibliotheque Nationale de France Supp. Turc 295 (F)'tir. Şâhî Dîvânı'nın İ nüshası, şair henüz hayatta iken 1489'da istinsah edilmiş olup muhtemelen onun kontrolünden geçmiştir. Bu yazmada 109 şiir mevcuttur. Bunlardan 95’i diğerlerinde yok iken 3'ü F'de ve 7'si D (İngiltere nüshaları)'de de bulunmaktadır. Şiirlerin 4'ü ise bütün nüshalarda vardır. Şiirlerin 85’i remel bahrinin fā'ilātün fā'ilātün fā'ilātün fācilün, 1’i fecilātün fecilātün fe'ilātün fecilün;

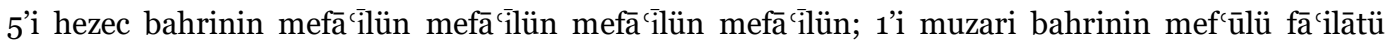
mefāçilü fā'ilün kalıbı ile yazılmıştır. Nüshadaki 17 rubai ise ahreb kalıpları ile kaleme alınmıştır. Dîvân'ın F nüshası bir mecmua içindedir. Toplam 86 şiir ihtiva etmektedir. Şiirlerden 57’i yalnız bu yazmada bulunmakta iken 3'ü İ ve 22'si D'de de vardır. 4 şiir ise bütün nüshalarda ortaktır. F'deki şiirlerin 75’i remel bahrinin fācilātün fācilātün fācilātün fācilün, 1’i fe'ilātün fecilātün fecilātün fecilün;

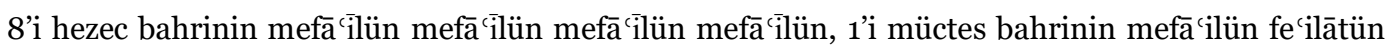
mefā cilün fe'ilün kalıbı ile yazılmıştır. 1 terci'-bendin vezni ise ahrebdir. Böylece yeni nüshalarla 155 yeni şiir ortaya çıkmaktadır.
\end{abstract}

Anahtar kelimeler: Şâhî Mesud Mirza, divan, Timur Ailesi, Çağatay edebiyatı.

\section{Two New Manuscript Copies of Shāhī Dīvān}

\begin{abstract}
Mesud Mirza (d. 1510) is one of the middle Asia poet lived in fifteenth century. His strain goes to Timur-i Gyurgyan (d. 1405). His father Mahmud Mirza (d. 1495) was a king in provinces of Khorasan, Hesar, Badahshan and Samarkand. Mesud Mirza has two divan, Turkish and Persian, and his penname is "Shāhī" for Turkish poems and "Ārifi" for Persian. We have known that the divan's two manuscript copies are in India Office Library. These were introduced by J. Eckmann in 1970. Later T. Mirzaev and M. Tekcan puplished these in 2001 and 2005 completely. Now, we learn about the existence of two manuscript copies more in Iran, we will show it with symbol of I, and Paris, we will show it with symbol of F. In this article we analyze these copies and peruse poems directionally additives to divan. The first manuscript I written in 1489, also Shahi Mesud Mirza was in life in that year, so we guess that he checked it entirely. There are 109 peoms in it and 95 poems of them are not in other manuscripts. These poems' measure is ramal's fā cilātun fā'ilātun fā cilātun fā cilun mostly. The second manuscript is $\mathrm{F}$ that takes part in a macmua and it has 87 poems. 57 poems of these are not
\end{abstract}

Prof. Dr., Marmara Üniversitesi, Fen Edebiyat Fakültesi, Türk Dili ve Edebiyatı Bölümü, uaslan@marmara.edu.tr [Makale kaylt tarihi: 17.1.2018-kabul tarihi: 14.4.2017] 
in Iran and Britain's manuscripts. The most of these is written with ramal's fā'ilātun fā ilātun fā cilātun fā'ilun. As a result we find out that, these two new copies of Shahi divan has 155 poems, also these are not in other copies.

Key words: Shāhī Mesud Mirza, divan, Timur Dynasty, Caghatay poetry.

\section{Giriş: Şâhî Mesud Mirza ve Eseri}

\subsection{Hayatı}

Mesud Mirza 15. yy.da yaşamış Orta Asya şairlerindendir. Babası Sultan Mahmud Mirza (857/1453901/1495) Horasan, Hisar ve Bedahşan vilayetlerini yönetmiş, son olarak 900/1494'te altı ay Semerkand hakimi olmuştur. Sultan Hüseyn-i Baykara (öl. 912/1506) ile iki kez savaşmış, her ikisinde de yenilmiştir. Annesi, Mir Büzürg-i Tirmizînin kızı Hanzade Begim’dir. Dedesi Ebu Said Mirza (öl. 874/1469) 855/1451-874/1469 yılları arasında on sekiz yıl boyunca Maveraünnehir ve Horasan'da saltanat sürmüştür (Lugal 2011: 581-588). Mesud Mirza’nın soyu Timur-ı Gürgân (737/1336808/1405)'a ulaşır. Mesud Mirza, Sultan Mahmud'un beş oğlu ile on bir kızının en büyüğüdür. Babası, henüz hayatta iken Hisar'ın yönetimini ona vermiştir (Arat 2006: 159, 163-165, 167).

Mesud Mirza 901/1495’te amcası Sultan Ahmed Mirza'nın kızı Ak Begim ile evlendi. 902/1496'da Sultan Hüseyn-i Baykara'nın Hisar'ı kuşatması üzerine şehirden çıkmak zorunda kaldı. Bir süre sonra Sultan Hüseyin kuşatmadan vaz geçince yeniden Hisar'a döndü. Aynı yıl Bâbür'le ittifak yaparak Semerkand üzerine yürüdü. Bu esnada ikinci evliliğini Şeyh Abdullah Barlas'ın kızı ile yaptı. Bâbür'e göre Mesud Mirza, Şeyh’in kızına çok düşkündü ve Semerkand'a gelişinin asıl sebebi de buydu (Arat 2006: 176). Mesud Mirza 903/1497'de atabeyi ve en yakın adamı olan Hüsrev Şah ile kardeşi Baysungur'un birlikte Hisar'a saldırması üzerine onlara karşı koyamadı ve Horasan'a giderek Sultan Hüseyin'e sığındı (Arat 2006: 199-200). Bu dönemde Alî Şîr-i Nevâyî (öl. 907/1501) ile tanışmıştır. Nevâyî, tezkiresinde onu "zeki, dürüst ve cömert bir genç” olarak anlatmaktadır (Eraslan 2001: 200). Fakat bir süre sonra ortaya çıkan karışıklıklar yüzünden Horasan'da da duramayan Mesud Mirza, Hüsrev Şah’a güvenerek yeniden Hisar'a döndü. Mesud Mirza'nın bu kararı kendisi için iyi olmamıştır, zira Hüsrev Şah onun gözlerine mil çektirmiştir. Zulüm ve fitne ile anılan Hüsrev Şah’ın yapmış olduğu kötülüklere Bâbür de temas etmektedir (Arat 2006: 159, 166). Mesud Mirza’ya bağlı birkaç yakın adamı onu gizlice önce Semerkand'a, oradan tekrar Horasan'a götürdüler. Sultan Hüseyin gözlerini kaybeden Mesud Mirza’ya iyi davranmış, hatta onu kızıyla evlendirmiştir. Böylece Mesud Mirza üçüncü evliliğini Sultan Hüseyin’in kızı ile yapmıştır (Arat 2006: 200-201). Mesud Mirza son yıllarını Horasan'da geçirmiş, bu esnada 912/1506'da Herat'ta Bâbür'le bir ziyafette görüşmüştür (Arat 2006: 366). 913/1507'de Şiban Han (öl. 916/1510)'ın Herat'ı kuşatması sırasında Özbekler tarafından öldürülmüştür (Eckmann 2003: 290).

Bâbür'ün Hâtırât’ında verdiği bilgiye göre Mesud Mirza'nın kızlarından birinin adı Sultan Baht Begim'dir (Arat 2006: 573).

\section{Eseri}

Mesud Mirza, sanat ve edebiyatın desteklendiği bir ortamda yetişmiştir. Babası Sultan Mahmud da şairdi ve bir dîvân tertip etmişti. Ancak Bâbür'e göre şiirleri seviyesiz ve tatsızdı (Arat 2006: 163).

“'Ārifi” mahlası ile Farsça ve "Şāhī” mahlası ile Türkçe şiirler söyleyen Mesud Mirza'nın orta seviyeli bir şair olduğu ileri sürülmüştür (Eckmann 2003: 290). Bu makalenin konusu olan Mesud Mirza Şâhî 
Dîvânı'nın incelediğimiz yeni nüshalarında öbür nüshalarda bulunmayan 155 adet şiir ortaya çıtığına göre şairin edebî kişiliğine dair önceden verilmiş hükümleri yeniden gözden geçirmek bir zorunluluk olmuştur. ${ }^{2}$

\subsection{Divan Nüshaları}

Mesud Mirza Şâhî Dîvânı'nın İngiltere nüshaları daha önce J. Eckmann tarafından tanıtılmıştı (2003: 287). India Office Kitaplığı'nda bulunan bu nüshalar:

1- Turki MS 23: Her sayfası 12 satır olup 57 varaktır. Nestalik hatla yazılmıştır. Eserin istinsah tarihi 10 Recep 1157 (13 Temmuz 1745)'dir. 2- Turki MS 25: Her sayfası 15 satırdır. 126 varaklık bir mecmuanın 81b-126a yaprakları arasında yer almaktadır. Nestalik hatla 26 Ramazan 1190 (8 Ağustos 1776)'da istinsah edilmiştir.

Her iki nüshada “152 gazel, 1 terci-bend, 37 rubai ve 18 müfred” vardır. Eckmann’a göre ikinci nüsha ilk nüshadan kopyalanmıştır (2003: 287).

J. Eckmann, ilgili makalesinde şairin hayatı ile ilgili verdiği bilgilerden sonra Dîvân'dan örnekler sunmaktadır (2003: 287-310). Daha sonra Töra Mirzaev, aynı iki nüshayı karşılaştırarak şiirlerin tamamını Özbekistan'da yayımlamış (2001); Türkiye'de ise M. Tekcan (2005)3 ve S. Bal (2013) aynı nüshaları esas alan çalışmalar yapmışlardır.

\section{2. Şâhî Divanı'nın İki Yeni Nüshası}

Şâhî Dîvânı'nın İngiltere nüshaları dışında iki nüshası daha tespit edilmiştir. Bunlar:

1- Kitâb-hâne-yi Devlet-i 'Aliyye-yi Îrân, Nu. 2205.4 Bu nüshanın kaydı, T.C. Kültür ve Turizm Bakanlığı Türkiye Yazmaları'nda da mevcuttur (https://www.yazmalar.gov.tr/detay_ goster.php?k= 104698, erişim tarihi 24/01/2017, sa. 13, 20). Nüsha, F. Kılıç tarafından sathi bir şekilde tanıtılmış, dolayısıyla kıymeti gerektiği gibi ortaya konulamamıştır. Kılıç bu nüshanın, müellif hattı veya divanın ilk versiyonu olabileceğini, şiir sayısının ise İngiltere nüshalarında yer alanlardan daha az olduğunu söylemektedir. Yazar, İran nüshası ile İngiltere nüshalarını karşılaştırmadığı için bu nüshada daha önce yayımlanmamış şiirlerin olup olmadığı hususuna hiç değinmemektedir. Kılıç’ın verdiği bilgiler şu şekildedir (2007: 392-393):

"Tarafımızdan incelenen Şâhî divanı nüshası İran Devlet Kütüphanesi (Kütübhâne-i Devlet-i aleyh-i [aliyye-yi] Îrân)'nde 385 numarada kayıtlıdır. İngiltere'de bulunan divanlardan daha az sayıda şiir ihtiva eden bu nüshanın en önemli özelliği tarihinin eskiliğidir. Eser müstensih Sultan Alî Meşhedi tarafından 895/1489'de istinsah edilmiştir. İngiltere'de bulunan nüshaların 18. yüzyll $(1745,1776)$ da istinsah edildiği hatırlanırsa bu nüshanın önemi ortaya çıkar. Kaynaklar Şâhînnin ölüm tarihi olarak 1507'yi verdiğine göre nüsha şairin ölümünden 18 yll önce istinsah edilmiştir. Yazmanın, divanın ilk versiyonu olma ihtimali de vardır. İngiltere'deki nüshalarda şiir sayısı daha fazla olduğuna göre şu anda bilinmeyen bir nüsha ya da müellif hattı olmalıdır. 31 varak, 11-12 satır ve nestalik hatlı olan nüsha mürettep değildir. 10 gazelin başının ya da sonunun eksik olduğu yazmada

Biz Şâhî divanını yeniden hazırlıyoruz, çalışmamızda şairin edebî yönünü ayrıntılı bir şekilde ortaya koyacă̆ız.

M. Tekcan'ın yayını bundan sonra D kısaltması ile verilecektir.

Dîvân'ın İran nüshası bundan sonra İ kısaltması ile verilecektir. 
97 gazel yer almaktadır... 3 gazel dışında kalan şiirlerde mahlasın yeri boş bırakılmıştır. 17 rubaî. Gazellerin biri hariç diğerleri remel bahrinin fâilâtün fâilâtün fâilâtün fâilün kalıbıyla yazılmıştır."

Şâhî Dîvânı'nın İran nüshası, şair henüz hayatta iken 895/1489'da Sultan Alî Meşhedî tarafından istinsah edildiğine göre müellif hattı olamaz, ancak şairin kontrolünden geçtiği düşünülebilir. Nüsha, İngiltere nüshalarından daha az şiir ihtiva ediyor olmakla birlikte, bu çalışmamızla ortaya koyduğumuz üzere 98 yeni şiir içermesi bakımından önemlidir. Yeni şiirlerin 82'si gazel, 16'sı rubaidir. İngiltere nüshalarında olup İran nüshasında da bulunan şiir sayısı ise 11'dir. Nüsha, ortadan birkaç yaprak eksik olup yanlış ciltlenmiştir. İçinde tespitimize göre 92 gazel ve 17 rubai olmak üzere toplam 109 şiir vardır. 1 şiiri ise sayfa görüntüsünün net olmaması yüzünden okuyamadık. Buradaki gazellerin 5 ’i hezec

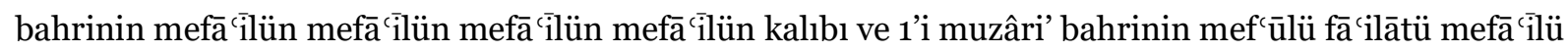
fā'ilün kalıbı ile yazılmıştır. Diğer gazeller ise remel bahrinden vezinlerle kaleme alınmıştır.

2- Bibliotheque Nationale de France Supp. Turc 295.5 Şâhı̂ Dîvânı, zikredilen kütüphanedeki

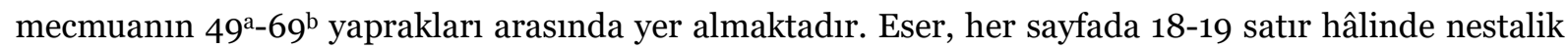
hatla yazılmıştır. Bu nüshada, D ve İ nüshalarında olmayan 57 şiir vardır. F nüshasında olup D nüshasında olan şiir sayısı 22, F'de olup I'de de yer alan şiir sayısı 3, bütün nüshalarda (F, D, İ) bulunan şiir sayısı ise 4'tür. F nüshasında toplamda 86 şiir bulunmaktadır. Bunlardan 75'sı gazel, 10'u tahmis ve 1’i eksik bir terci-bend'dir. Bu nüshadaki şiirlerin 8’i hezec bahrinin mefācilün mefācîlün mefā çlün mefā çilün kalıbı ile, 1’i müctes bahrinin mefācilün fe'ilatün mefā'ilün fe'ilün kalıbı ile yazılmıştır. Diğer şiirler ise remel bahrinin kalıpları ile kaleme alınmıştır. İ ve F nüshalarındaki şiirlerin vezinleri aşağıdaki tabloda bir arada verilmiştir:

Tablo 1:

\begin{tabular}{|c|c|c|c|c|c|}
\hline Nüsha & Bahir & Vezin & Şiir Numarası & Toplam & $\begin{array}{l}\text { Genel } \\
\text { Toplam }\end{array}$ \\
\hline \multirow[t]{4}{*}{$\dot{\mathrm{I}}$} & \multirow[t]{2}{*}{ Remel } & $\begin{array}{l}\text { fā'ilātün fā'ilātün } \\
\text { fắcilātün fā́cilün }\end{array}$ & $\begin{array}{l}1,2,3,4,5,6,7,8,9,10,11,12,13, \\
14,15,16,19,22,23,24,25,27,32, \\
34,35,38,39,40,43,49,51,54,55, \\
58,59,63,65,66,69,70,71,72,74, \\
76,77,78,83,84,86,90,91,92,94, \\
95,97,99,100,101,102,105,107, \\
108,109,111,114,117,119,122,124, \\
125,129,131,138,140,141,142, \\
143,144,146,147,150,151,153, \\
154,159\end{array}$ & 85 & \multirow[t]{4}{*}{109} \\
\hline & & $\begin{array}{l}\text { fe'ilātün fecilātün } \\
\text { fe'ilātün fe'ilün }\end{array}$ & 112 & 1 & \\
\hline & Hezec & 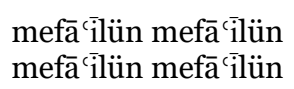 & $36,50,130,133,155$ & 5 & \\
\hline & Muzari & 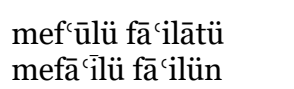 & 82 & 1 & \\
\hline
\end{tabular}




\begin{tabular}{|c|c|c|c|c|c|}
\hline & Ahreb & & $\begin{array}{l}162,163,164,165,166,167,168, \\
169,170,171,172,173,174,175,176, \\
177,178\end{array}$ & 17 & \\
\hline \multirow[t]{5}{*}{$\mathrm{F}$} & \multirow[t]{2}{*}{ Remel } & $\begin{array}{l}\text { fācilātün fācilātün } \\
\text { fā'ilātün fācilün }\end{array}$ & $\begin{array}{l}19,20,26,28,29,30,31,33,34,37, \\
41,42,44,46,47,48,49,53,56,57, \\
60,61,62,63,64,67,68,73,75,79, \\
80,81,85,87,88,89,91,93,98, \\
103,104,106,110,113,115,116,118, \\
121,122,123,126,127,128,134, \\
135,136,137,139,145,146,152, \\
156,158,160,161,179,180,181, \\
182,183,184,185,186,187,188\end{array}$ & 75 & \multirow[t]{5}{*}{86} \\
\hline & & $\begin{array}{l}\text { fecilātün fecilātün } \\
\text { fecilātün fecilün }\end{array}$ & 45 & 1 & \\
\hline & Hezec & 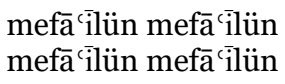 & $17,21,96,120,132,148,149,157$ & 8 & \\
\hline & Müctes & $\begin{array}{l}\text { mefācilün fe'ilātün } \\
\text { mefā'ilün fe'ilün }\end{array}$ & 18 & 1 & \\
\hline & Ahreb & & 189 & 1 & \\
\hline
\end{tabular}

İ, F ve D nüshalarındaki şiirler, yalnız bir nüshada bulunanlar ile nüshalarda ortak olanlar, aşağıdaki tabloda verilmiştir:

Tablo 2:

\begin{tabular}{|c|c|c|c|}
\hline Nüsha & Şiir Numarası & Toplam & $\begin{array}{l}\text { Genel } \\
\text { Toplam }\end{array}$ \\
\hline$\dot{\mathrm{I}}$ & $\begin{array}{l}1,2,3,4,5,6,7,8,9,10,11,12,16,22,23,24,27,32,35,36,38,39,40 \\
43,50,54,55,58,59,65,66,69,70,71,72,74,76,77,78,82,83,84,86 \\
90,92,94,95,97,99,100,101,102,105,107,108,109,111,112,114,119 \\
124,125,129,130,131,133,138,140,141,142,143,144,147,150,151,153 \\
154,155,159,162,163,164,165,166,167,168,169,170,171,172,173,174 \\
176,177,178\end{array}$ & 95 & \multirow[t]{4}{*}{109} \\
\hline İ, F & $49,91,146$ & 3 & \\
\hline$\dot{\mathrm{I}}, \mathrm{D}$ & $13,14,15,25,51,117,175$ & 7 & \\
\hline$\dot{\mathrm{I}}, \mathrm{D}, \mathrm{F}$ & $19,34,63,122$ & 4 & \\
\hline $\mathrm{F}$ & $\begin{array}{l}17,18,21,26,28,29,37,42,47,56,57,60,61,64,73,75,79,80,87,88, \\
89,93,96,98,103,104,106,110,113,115,116,120,123,127,134,135,136, \\
137,139,148,149,152,157,158,160,161,179,180,181,182,183,184,185, \\
186,187,188,189\end{array}$ & 57 & \multirow[t]{4}{*}{86} \\
\hline $\mathrm{F}, \dot{\mathrm{I}}$ & $49,91,146$ & 3 & \\
\hline $\mathrm{F}, \mathrm{D}$ & $\begin{array}{l}20,30,31,33,41,44,45,46,48,53,62,67,68,81,85,118,121,126,128 \\
132,145,156\end{array}$ & 22 & \\
\hline $\mathrm{F}, \mathrm{D}, \dot{\mathrm{I}}$ & $19,34,63,122$ & 4 & \\
\hline
\end{tabular}


Two New Manuscript Copies of Shāhī Dīvān / Ü. Aslan (p. 99-126)

Tabloya göre yalnız İ nüshasında olan şiir sayısı 95, yalnız F'de bulunan şiir sayısı 57, İ ve F nüshalarında ortak olan şiir sayısı ise 3’tür. Buna göre yalnız İ ve F nüshalarında 155 yeni şiir yer almaktadır ve bunlar D'de yoktur.

\section{3. İ ve F Nüshalarındaki Şiirler}

İ ve F nüshalarındaki şiirlerin tamamının matla beyitlerini elifbâ sırasına göre ve D ile karşılaştıralarak aşağıda veriyoruz: ${ }^{6}$

gazeliyyāt

\section{ḥarfü'l-elif}

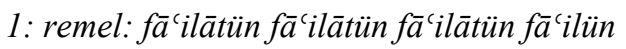

zār ol-kim ġam bile ḳaşımġa yārım kèlmäsä

müşkil-aḥvāli eger ol ġam-küsārım kèlmäsä (İ 28 ${ }^{\mathrm{a}}$, F-, D: XXV)

\section{ḥarfü't-tā}

2: remel: fấcilātün fắcilātün fấcilātün fấcilün

sẻndin ètmän özgälik çūn dedin èy āb-1 ḥayāt

veh yana cānā bu sözdin özgä ger bolsan uyat (I 4

3: remel: făcilātün făcilātün fấcilātün făcilün

sèn ü 'işret bezmid[ä] mey nūş ètip èy yār mest

mèn ü miḥnet küncid[ä] gam dāmı birle pāy-best (İ 17ª , F-, D-)

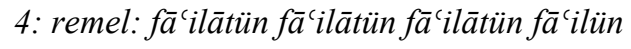

kim dèdi kim cevrni nāzük-mizācıngä yavut

mihr körküzmäy könülni mihribānlıḳdın savut (I 4 ${ }^{\text {b }}$, F-, D-)

5: remel: făcilātün făcilātün fấcilātün fấcilün

èy lețāfet allıda serv-i sehỉ bālā yigit

v'èy melāḥat gülşeni içre gül-i ra'nā yigit (İ 1 ${ }^{\text {b }}$, F-, D-)

6: remel: făcilātün fácilātün făcilātün fấcilün

yana taptım bir sehī-ḳad 'ārıż[1] gül-gūn yigit

țab'i hem ruhsārı ḳaddı dèk besī mevzūn yigit (İ 17ª F-, D-)

6 Bu bölümde yer alan beyitler, özel adlar hariç, küçük harflerle yazılmıştır. Kullanılan kısaltmalar ve işaretler: - "nüshada yok”, [...] "metinde okunamayan kısım”, [ ] "metne tarafımızdan eklenen kısım”, a "varağın sağdan ön yüzü, b "varağın sağdan arka yüzü". 


\section{ḥarfü'l-cīm}

7: remel: fā́cilātün fā'ilātün fā'ilātün fấcilün

ḥāl-1 mènni āhır ol nā-mihribān bilgäy mü hīç

bilse hạâlımnı bu sarı veh yana kẻlgäy mü hî̧̄ (İ $28^{\text {b }}$, yaprak kopmuş; F-, D-)

\section{harfü'r-rā}

8: remel: fā'ilātün fă'ilātün fấcilātün fācilün

çūn huumārım ḳașd-1 cān eylär nihān u āşikār

sāḳiyā gül-gūn ḳadeh tut kim belā èrmiş humāār (İ 13ª , F-, D-)

9: remel: fā'ilātün fā'ilātün fā'ilātün fā'ilün

hatțt-1 sebznin mu-durur la lin üze èy gül- 'izār

yā tutuptur çeş̧me-yi hayvāan lebidä sebzezār (İ 27ª , F-, D-)

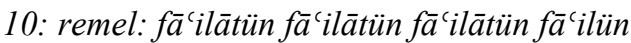

dehr ara mị̣net olsa mị̣net-ābādımda bar

her elem kim bolsa ol hem cān-1 nā-şādımda bar (İ 22 b , F-, D-)

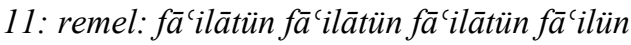

ḳayda kim meclis ara ol serv-i gül-ruhsār bar

gülbün-i 'işretdin anda her nè dèsäm bār bar (İ 20 b F-, D-)

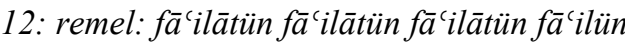

şekve bì-keslik uçūn dehr içrä nèdip eylägäy

ol ser-i kū itläri dèk kimni kim aḥbābı bar (İ 11 a , bir yaprak kopmuş; F-, D-)

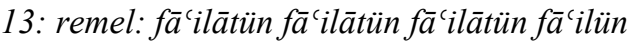

èy köyül ol serv-i dil-cūnın ki sẻndin 'ārı bar

gerçi ol kẻlmäs sẻnin sarı sẻn anın sarı bar (İ 26 ${ }^{\text {b }}$, bir yaprak kopmuş; F-, D: L)

ġonçanı tar ag̉zıg̉a né dèp ḳılay teşbịh kim

ġonçanın güftārı yoḳtur aġzın[ın] güftārı bar (İ 24a, 13 . şiirin devamı olmalıdır.)

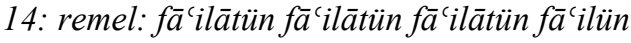

veh ki bir bir dostlar mèndin cüdālık kıldılar

körsätip mihr evvel āhır bī-vefālıḳ kıldılar (İ 21 a , F-, D: XLVIII) 
Two New Manuscript Copies of Shāhī Dīvān / Ü. Aslan (p. 99-126)

15: remel: fā'ilātün fā'ilātün fā'ilātün fācilün

ger ėmäs-mèn kūyụ içre mihrin ammā cāndadur

mèn egerçi munda-mèn cān birle kọ̈lüm andadur (İ 13ª , F-, D: XLVII)

16: remel: fā'ilātün fā'ilātün fā'ilātün fā'ilün

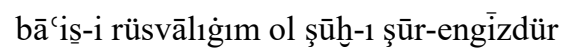

kim anı̣ la li ġamıdın közlärim hūn-riżdür (İ 10º F-, D-)

17: hezec: mefā‘īiün mefācīlün mefācīlün mefācìlün

ḳayan barsạ ayag̉ baştın ḳılur her kim ki cānlığgdur

netäy ammā mėni salġan ayag̉dın nā-tevānlıġdur (İ-, F 49º , D-)

18: mücteș: mefāilïn fe'ilātün mefācilün fe`ilün

garīblıḳda yana hāṭ̂ıım periş̧āndur

garībraḳ bu ki nè ser maya nè sāmāndur (İ-, F 49ª D-)

19: remel: fā'ilātün fấcilātün fấilātün fā'ilün

cānım èrmiş ol ki hicrān derdidin bī-çāredür

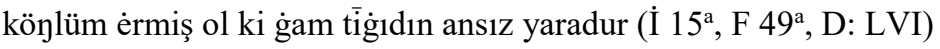

20: remel: fā'ilātün fā'ilātün fā'ilātün fā'ilün

ẓulm ėtär ol hūb-rū kọ̈lidä mèndin kīn müdür

hūb-rūlar içre yā zulm eylämäk āyīn müdür (İ-, F 49ª , D: LI)

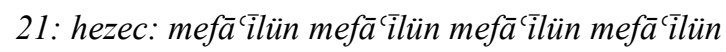

fırāḳındın ölär hāālatda çihrem zag̉ferānīdür

naẓar hạalımġa sal kim bāg̀-1 ‘ömrümnin hazānıdur (İ-, F 49º , D-)

22: remel: fā'ilātün fā'ilātün fā'ilātün fā'ilün

nèçe kim ol bī-vefāsılik bile meşhūr èrür

lìk istär-mèn vefāsın anca kim maḳdūr èrür (İ 26ª F-, D-)

23: remel: fā'ilātün fấcilātün fā'ilātün fā'ilün

zār-mèn ėy yār kèl kèl ḥālet-i zārımnı kör

hạalet-i zārımnı aylap cān-ı bīmārımnı kör (İ 15ª , F-, D-)

24: remel: fā'ilātün fā'ilātün fā'ilātün fā'ilün 
her kesī sèver köyülüm 'ışḳıdın şeydā bolur

veh nẻ şeydā kim barı (ālem ara rüsvā bolur (İ 15 , F-, D-)

25: remel: fācilātün făcilātün făcilātün fācilün

bir küni kim mana ol nā-mihribān hem-dem bolur

şādlıḳ cānım ḳ1lıp ġamkīn köyül bì-g̀am bolur (İ 20ª , F-, D: LII)

26: remel: fā'ilātün fā'ilātün fấcilātün fācilün

her ḳaçan kim mihrsiz yārım mana hem-dem bolur

cān-1 nā-ḩoşnūd hoş gamkīn köyül bì-gam bolur (İ-, F 49º, D-)

\section{harfü'z-zā}

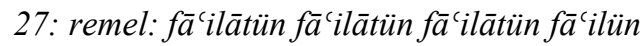

veh nè gam ol yārg̉a ger bolsa mèn dèk zārsız

gam manadur kim bola alman demī ol yārsız (İ 29a , F-, D-)

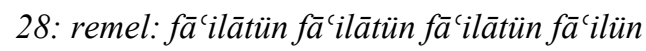

boldı cānān mihrsiz cevrin çèkädür cān henūz

cān ölüm ḥālıgà vü raḩm äylämäs cānān henūz (İ-, F 50ª , D-)

29: remel: fấcilātün fā'ilātün fā'ilātün fā'ilün

èy țarab-sāzın tüzärdä nāzenīn üstādımız

her maḳāmī bolsa nāznın șăḥib-i irşādımız (İ-, F 50ª , D-)

\section{ḥarfü's-sīn}

30: remel: fā'ilātün fắcilātün fắcilātün fā́cilün

hergiz ol bì-raḥm ḥālımġa teraḥhum äylämäs

zulm äyläp otluk āhımdın tevehhüm äylämäs (İ-, F 50º D: LXVII)

\section{1: remel: fā'ilātün fā'ilātün fă'ilātün fā'ilün}

veh ki vīrān ‘ömrüm öyi vaṣl ilän ābād èmäs

hecr ara maḥzūn köyül gaam ḳaydıdın āzād èmäs (İ-, F 50ª, D: LXVI)

\section{2: remel: fấcilātün fă'iātün fā́cilätün fā́cilün}

bes ki 'işret külbesi sènsiz mana menzil èmäs

anıy uçūn mana 'işret sènsizin hāṣı̣l èmäs (İ 8ª F-, D-) 
Two New Manuscript Copies of Shāhī Dīvān / Ü. Aslan (p. 99-126)

33: remel: fā'ilātün fā'ilātün fā'ilātün fācilün

lebläridin çūnki kām-1 dil maya ḥāṣıl èmäs

èy köyül ḳan yut ki ḥāṣıl gayr-1 hūn-1 dil èmäs (İ-, F 50º, D: LXVIII)

34: remel: fācilātün fā'ilātün fầ ilātün fā'ilün

gerçi gerdūn ẓulmıdın bir menzil ābādān èmäs

hịç kişinin mèn belā-keş dèk öyi vīiān èmäs (İ $3^{\mathrm{b}}, \mathrm{F} 50^{\mathrm{b}}$, D: LXIX)

\section{harfü'ș-șin}

35: remel: fā'ilātün fā'ilātün fā'ilātün fā'ilün

[veh] bu ki mèndin [o] yār aysız cüdālıḳ äylämiş

terk ètip mihr ü vefānı bī-vefālık äylämiş (İ 22a , F-, D-)

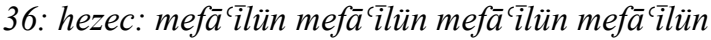

yüzin pinhān ḳılurnı ol perī tā ihtiyār ètmiş

fỉgān kim uşbu ḳayğudın mèni dīvāne-vār ètmiş (İ 26a , F-, D-)

37: remel: fācilātün fā'ilātün făcilātün fācilün

serv-ḳaddi kim yèri bāg̀g-1 cihān-ārā èmiş

tāze çıḳkan ḳāmeti şāh̆-1 gül-i ra'nā èmiş (İ-, F 51ª, D-)

38: remel: fā'ilātün fā'ilātün fầilātün fā'ilün

veh yana ol ay yüzin körär zamān hem bar èmiş

körär uçūn bilmädim cismimdä cān hem bār èmiş (İ 8a , F-, D-)

39: remel: fā'ilātün fā'ilātün fầilātün fā'ilün

bar ėmiş bighāne mèndin anda kim ag̉yār èmiş

her ḳaçan èl bolmasa ol yār mana yār èmiş (İ 10a , F-, D-)

40: remel: fācilātün fācilātün fācilātün fācilün

sẻnsizin èy dil-rubā mey içmägim müşkil èmiş

her nė içsäm mey èmäs bildim ki hūn-i dil èmiş (İ $6^{\text {b }}$, F-, D-)

41: remel: fācilātün fā'ilātün fầ ilātün fā'ilün

ḳaṣd-1 cānım äylägän bī-mihr cānānım èmiş

ol kim anı dost dèr-mèn düşmen-i cānım ėmiş (İ-, F 51º , D: LXXII) 
42: remel: fācilātün fā'ilātün fā'ilātün fā'ilün

yārsız ölmäk devā-yı miḥnet-i hicrān èmiş

müşkil èmdi kim firāḳııdın ölüm āsān èmiş (İ-, F 51ª, D-)

43: remel: fācilātün fācilātün fā'ilātün fā'ilün

bī-vefālarnı̀ işi geh cevr ü gāhi kīn èmiş

'ayb ėmäs ol hayl ara bu şivelär āyīn èmiş (İ 12a, F-, D-)

44: remel: fācilātün fācilātün fācilātün fācilün

cennetü'l-me'vā ki dèrlär yārnın kūyı èmiş

vaṣf-1 ṭūbā kim ḳılurlar ḳadd-1 dil-cūyı èmiş (İ-, F 51ª, D: LXXI)

\section{ḥarfü’l-ġayn}

45: remel: fe ‘ilātün fecilātün fecilātün fecilün

veh ki bardı naẓarım elidin ol yār dirīi

guuṣṣa vü derd-i firāḳ ètti mèni zār dirìg (İ-, F 51º , D: LXXVIII)

46: remel: fā'ilātün fā'ilātün fā'ilātün fāiilün

sèn ü 'işret birle ‘ālem ḳaydıdın āzādlı̀g

mèn ü miḥnet ḳaydı vü gaam küncidä nā-şādlı̀ (İ-, F 52ª, D: LXXX)

47: remel: fā'ilātün fā'ilātün fā'ilātün fā'ilün

èy perī tā äylädin '‘şḳ ehlidin bīgānelı̀g

artadur '1şḳııda her sā' at maya divīnelı̀ (İ-, F 52ª D-)

\section{ḥarfü'l-fā}

48: remel: fā'ilātün fā'ilātün fā'ilātün fā'ilün

veh ki ‘ömrüm żāyi` ötti barça nā-dānlığgda ḩayf

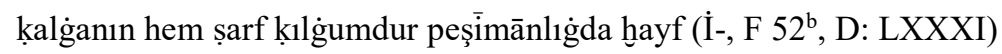

\section{ḥarfü'l-ḳāf}

49: remel: fācilātün fācilātün fācilātün fāi ilün

ayrılıp ḳalğunca sẻndin çı̣̣sa cānım yahş̧ırạ

sènsiz èy cān bolġanımdın bolmaġanım yahşıraḳ (İ 16 ${ }^{\text {b }}$, F 53ª, D-)

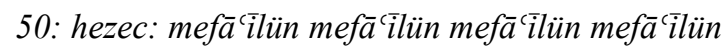

közümgä ḳayg̉urup dėsäm nè èrdi köyül aldurmaḳ 
Two New Manuscript Copies of Shāhī Dīvān / Ü. Aslan (p. 99-126)

ol aytur ger könül èrdi kèräkmäs munca ḳayġurmaḳ (İ 2a , F-, D-)

51: remel: fā'ilātün fā'ilātün fā'ilātün fā'ilün

köylüme kār ètmäsün mü derd ü gurbet èy refīḳ

yār barıp ḳoydı cāng̉a dāg̀-1 furḳat èy refīḳ (İ 25ª , F-, D: LXXXIV)

remel: fācilātün fā'ilātün fācilātün fā'ilün

cānıma sançılmasun mu ḩār-1 ġurbet èy refīḳ

kim köyülgä ḳoydı ol gül dāg்-1 furḳat èy refīḳ (İ-, F 52 ${ }^{\text {b }, ~ D-. ~ 51 . ~ s ̧ i i r i n ~ d e g ̆ i s ̧ i k ~ b i r ~ b i c ̧ i m i ~ o l a b i l i r .) ~}$

52: remel: fā'ilātün fā'ilātün fầilātün fā'ilün

ḳaṣd-1 cānım ḳıldılar çūn ehl-i devrān èy refị̄

hạacet èrmästür meded ḳılmaḳga hicrān ėy refîk (İ-, F 52 b , D: LXXXIII)

53: remel: fācilātün fācilātün fācilātün fācilün

äylägil èy tünd-hū mèn zār birle yārlık

yoḳsa hod dāyim işindür äylämäk bīzārlıḳ (İ 20º , F-, D-)

54: remel: fā'ilātün fā'ilātün fầilātün fā'ilün

çūn yoḳ ol devlet ki ḳılsam yār ılan dem-sāzlık

bārī anı̣ itläri birle ḳılay hem-rāzlı̣ (İ 23º , bir yaprak kopmuş, F-, D-)

\section{harfü'l-kāf}

55: remel: fācilātün fā'ilātün fā'ilātün fā'ilün

şerḥ-i ḥālımnı nẻ dèy sẻnsiz ki miḥnet kūyıda

āhır äylädi elind[in] köp ġamın cismi[mni] hāak (İ-, F 54ª, D-)

56: remel: fā'ilātün fā'ilātün fầ ilātün fā'ilün

ol ser-i kūy içre yüz ḳatla gedālı̣̣ äylämäk

yahşıraḳ kim özgä yèrdä pādişālıḳ äylämäk (İ-, F 53ª, D-)

57: remel: fācilātün fā'ilātün fā'ilātün fā'ilün

ałladın mu ėy vefā țavrıda bì-hem-tā mīrek

kim tapılmas sèn kėbi mīr-zādelärdin emīrek (İ 10a , F-, D-)

58: remel: fācilātün fācilātün făcilātün fācilün

mėndin ayrılma ḥużūrum çūnki bardur șıḥhatı̣ 
bī-ḥużūr ètsän mèni èl ḳılġusıdur rag̉betin (İ 27ª , F-, D-)

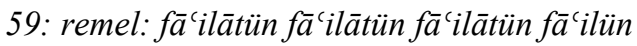

yār sebz ü sebz-i haț̣t āfet-i dīndür bilin

lebläri birle be-gāāyet sebz-i şīinndür bilin (İ-, F 54ª , D-)

60: remel: fā'ilātün fã 'ilātün fā'ilātün fā'ilün

atlanıp èy hüsn haylı her țaraf cevlān ḳılın

nār-1 rahşıın segritip 'ış̣ ehlini hayrān ḳı1ın (İ-, F 53ª D-)

61: remel: fā'ilātün fấcilātün fắcilātün fắcilün

hecr derdig̉a șanemlär vaṣl ilä dermān ḳılın

yoḳsa siz hem bir künī endiş̧e-i hicrān ḳılın (İ-, F 54ª , D: LXXXV)

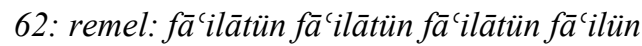

şām-ı hicrānımdur ol kim intihāsı yoḳ anı̣

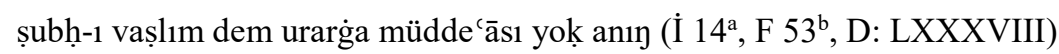

63: remel: fā'ilātün fā'ilātün fā'ilātün fācilün

èy sehī-ḳad kim ėmästür serv boydaşıı sẻnin

gamzen oḳın cāng̉a urmış köz-ile ḳaşıy sẻnin (İ-, F 53º , D-)

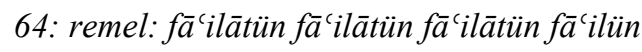

sana ohş̧ar hūublardın hịç kişim yoḳtur mènin

sėndin özgä özgälär birle işim yoḳtur mėnin (İ 13 $3^{\text {b }}$, F-, D-)

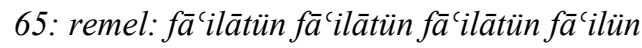

bar ėmiş ėy hūūb-rūlar içrä makșūuum mènin

naḳd-1 cān ḳılmaḳ fedā èlindä bihbūdum mènin (İ 29a , F-, D-)

\section{ḥarfü'l-lām}

66: remel: fā'ilātün făcilātün fă'ilātün fā'ilün

zār köylüm kim saçıy sevdāsıdın şeydādur ol

tèlbelik ḳılsam 'aceb yoḳ bā'iš-i sevdādur ol (İ-, F 55ª , D: CII)

67: remel: fā'ilātün fấcilātün fấcilātün fā́cilün

gül gül olsa ‘ārıżı meydin gülistānımdır ol 
Two New Manuscript Copies of Shāhī Dīvān / Ü. Aslan (p. 99-126)

cilveger olsa ḳadı̄ serv-i ḩırāmānımdır ol (İ-, F 55a, D: XCVIII)

68: remel: fā'ilātün fā'ilātün fā'ilātün fācilün

naḩl-1 `ömründin müdām èy serv ber-ḩurdār bol

gerçi mèn ḳayġuy bilän boldum 'adem sèn var bol (İ 28 a, F-, D-)

69: remel: fā'ilātün fā'ilātün fầilātün fā'ilün

ger dèsäy sırrımnı bilgäy-sèn demì bīzār bol

oyġanıp mèn nā-tevānga șāhib-i esrār bol (İ 7ª , F-, D-)

70: remel: fā'ilātün fā'ilātün fầilātün fā'ilün

èy közüm çūn körmäy ol ay yüzini bī-nūr bol

ḳaysıdur bī-nūr bolmaḳ belkim ansız kūr bol (İ 3 $3^{\mathrm{a}}, 15^{\mathrm{b}}$ tekrar, F-, D-)

71: remel: fācilātün fā'ilātün fầilātün fā'ilün

èy könül ḳurbān-1 vaṣlı ol meh-i ruhsāara bol

yoḳsa ansız tìg-1 hicrān birle yüz min pāre bol (İ 19ª , F-, D-)

72: remel: fā'ilātün fā'ilātün fấcilātün fā'ilün

èy mèni bir dil-rubā 'sşḳ̂da zār ètkän köyül

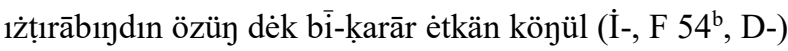

73: remel: fācilātün fācilātün făcilātün fācilün

yārdın yüz derd èrür cānımġa peydā èy köyül

ol sebebdin bolmışam 'ālemġa rüsvā èy könül (İ 6a , F-, D-)

74: remel: fācilātün fā'ilātün fầilātün fā'ilün

āh kim 'ış়̣ içre ḳıldı̣ bir temennā èy köyül

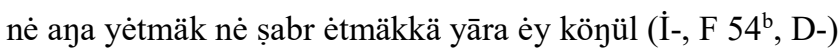

75: remel: fā'ilātün fā'ilātün fācilātün fā'ilün

közlädim her yėrdä yana țurfa maḥbūb ėy köyül

kim anıy dèk yoḳ-tur[ur] 'ālemdä bir hūūb èy könül (İ 24ª F-, D-)

76: remel: fācilātün fā'ilātün fā'ilātün fā'ilün

mey içip ol yārdın ḳıldım şikāyet èy köyül

mestlıg̉dın ḥāletim ḳıldı sirāyet èy könül (İ 18 ${ }^{\mathrm{a}}$, F-, D-) 
77: remel: fā'ilātün fā'ilātün fầilātün fā'ilün

ol perī-rū dil-rubā körküzmäsä yüz èy köyül

hūblarnı körgä èmän bolsa ger yüz èy köyül (İ 14a , F-, D-)

78: remel: fācilātün fācilātün făcilātün fācilün

‘āḳibet terk-i mahạabbet ḳıldı cānān èy köyül

dost èrdi boldı āhırır düşmen-i cān èy köyül (İ-, F 54º , D-)

79: remel: fācilātün fā'ilātün fā'ilātün fā'ilün

èy könül bī-ḥad mèni vaṣlığa ḩācetmend bil

vaṣl bergini hayātım nahlığa peyvend bil (İ-, F 55ª D-)

80: remel: fācilātün fā'ilātün fấilātün fầilün

èy köz ol ay yüzidin maḥrūm-sèn ḳan yı̈̇laġıl

v’èy könül tapmay viṣālın tartıp efḡān yıġlaġıl (İ-, F 55ª D: CI)

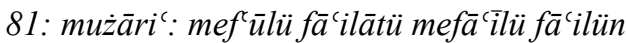

sāḳi humār derdidin öldüm șavāb ḳıl

zühd ü vera 'libāsını rehn-i şarāb ḳıl (İ 19º , sonu eksik; F-, D-)

82: remel: fācilātün fā'ilātün fā'ilātün fā'ilün

dèdim èy dil-ber ki köylüm hāāetin ma'lūm ḳıl

yoḳ ki yüzün körmägeydin közlärim maḥrūm ḳ1l (İ 11ª, F-, D-)

83: remel: fā'ilātün fā'ilātün fầilātün fā'ilün

èy perī-yüzlük nigārım ḥāletim nezẓāre ḳıl

ḥāletim nezzāre eyläp derdime bir çāre ḳıl (İ 6 $6^{\mathrm{b}}$, F-, D-)

84: remel: fā'ilātün fā'ilātün fā'ilātün fā'ilün

cānġa yèttim sẻndin ayru hecr ara èy yār kèl

kèlmäsäy n’ètsün ölär-mèn raḥm ėtip zinhā[r] kèl (İ-, F 55ª, D: C)

85: remel: fācilātün fấcilātün fầilātün fā'ilün

kẻlgil èy yārım mènin derdimġa dermān eylägil

nāz ile özünni cān dèk cism ara cān eylägil (İ 19ª , F-, D-)

harfü'l-mìm 
Two New Manuscript Copies of Shāhī Dīvān / Ü. Aslan (p. 99-126)

86: remel: fā'ilātün fā'ilātün fā'ilātün fā'ilün

èy könül ger eylädi ol dil-rubā luṭfını kem

lìk luṭfıdın ėmäs-mèn bir yolı nevmìd hem (İ-, F 57ª, D-)

87: remel: fācilātün fācilātün fācilātün fācilün

sāḳiyā yètti 'aceb mevsimdä eyyām-1 șıyām

bir nėçe kün kim ganīmetdür leb-ā-leb eyle cām (İ-, F 57ª D-)

88: remel: fācilātün fầilātün fā'ilātün fācilün

nè habīibi maya kim andın maḥabbat anlasam

nė refịịi kim anı körgäç meveddet aylasam (İ-, F 56 a , D-)

89: remel: fācilātün fācilātün fācilātün fā'ilün

yār ılan ötkän mecālisni eger yād eyläsäm

nè 'aceb ger ḥasretidin āh u feryād eyläsäm (İ 9a , F-, D-)

90: remel: fācilātün fācilātün fācilātün fācilün

cān bèrür-mèn her nefes ol dil-rubānı körmäsäm

vāy cānımġa mėnin ki bir kün anı körmäsäm (İ 12ª F 56º , D-)

91: remel: fācilātün fā'ilātün fā'ilātün fācilün

çūn ölär-mèn bir zamān cānā yüzünni körmäsäm

cān ḥarām er başııa körgändä cān èvürmäsäm (İ 6 $6^{\mathrm{a}}, \mathrm{F}-$, D-)

92: remel: fā'ilātün fā'ilātün fācilātün fācilün

köylüme bu kim teraḥḥum ḳılay eylär-sèn sitem

haddın aştı ėy cefā-pişse kèräkmäs munca hem (İ-, F 56ª D-)

93: remel: fā'ilātün fā'ilātün fā'ilātün fācilün

bu ġami kim mèndä bar ḳan yığlag̉ay-mèn lā-cerem

yètmäyin her dem firāvān yığlag̉ay-mèn lā-cerem (İ 18 a, F-, D-)

94: remel: fā'ilātün fā'ilātün fā'ilātün fā'ilün

ol kim istäydür mèni dil-ḩaste vü bī-çāre hem

yüzigä körmäs revā ḳılsam demī nezzāre hem (İ 26º , F-, D-) 


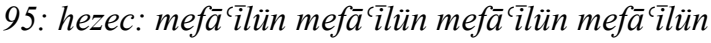

yana bir ay kelāmıda țariḳ-i dil-beri kördüm

köyül dīvāne boldı bilmädim gūyā perī kördüm (İ-, F 56 ${ }^{\text {b }}$, D-)

96: remel: fā'ilātün fā'ilātün fā'ilātün fā'ilün

bes ki la lin yādı birle ḳan tökä giryān közüm

'āḳibet-engīz ètär sėndin yıraḳ țug̉yān közüm (İ 2a , F-, D-)

97: remel: fācilātün fācilātün făcilātün fācilün

her nefes hecrindä derd-i bī-devāga uçradım

sèndin ayru tüşkäli türlük belāga uçradım (İ-, F 57ª D-)

98: remel: fācilātün fā'ilātün fācilātün fā'ilün

èy mėnin ḩod-kām yārım ḳayda èrdin bilmädim

kèlmädin kèce nigārım ḳayda ėrdin bilmädim (İ 7º , F-, D-)

99: remel: fấcilātün fā'ilātün fầilātün fā'ilün

hecridin munca maya miḥnet kèlürni bilmädim

vaṣl naḩlını̣ beri ḥasret kèlürni bilmädim (İ 12b , F-, D-)

100: remel: fā'ilātün fấilātün fā'ilātün fā'ilün

'1şk èligä ġam yėmek nā-çār ègänni bilmädim

veh munın-dèk '1şk işi düşvār ègänni bilmädim (İ 23 b , F-, D-.)

101: remel: fā'ilātün fā'ilātün fā'ilātün fācilün

baĥt-1 kūr kim mānic-i dīdār bolup țāli im

körmädim ‘ömrī sèni efsūs ‘ömr-i żāyi ‘im (İ 29º , F-, D-)

102: remel: fācilātün fācilātün fācilātün fācilün

dest bèrdi vādîi-yi hecr içre ser-gerdānlığım

ḳanı ol kim vaṣl birle bar èdi sulțānlı ġım (İ-, F 57b, D-)

103: remel: fā'ilātün fā'ilātün fā'ilātün fā'ilün

vāy u yüz min vāy kim yoḳtur bir andaḳ hem-demim

kim barıp allıda gāhi eylägäy şerh-i gamım (İ-, F 56ª D-)

104: remel: fācilātün fācilātün fā'ilātün fā'ilün

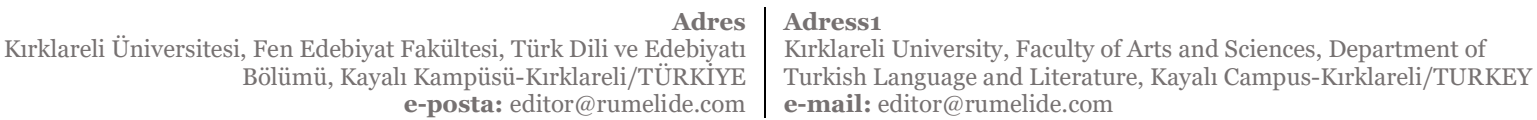


Two New Manuscript Copies of Shāhī Dīvān / Ü. Aslan (p. 99-126)

nėçe kim fārig̀ ėsäy èy cānġa hem-dem tuḳḳanım

bir yolı bizdin bu yạlı̀g bolma bì-gam tuḳḳanım (İ 5 $\left.{ }^{\mathrm{a}}, \mathrm{F}-, \mathrm{D}-\right)$

105: remel: fā‘ilātün fācilātün fācilātün fā‘ilün

buymış andaḳ miḥnet-i hecrindä bi $\bar{i}$-ḩodlug fenim

aylaman kim maya kimdür dost kimdür düşmenim (İ-, F 57º D-)

\section{ḥarfü'n-nūn}

106: remel: fācilātün fācilātün fācilātün fācilün

ḳalmadı nā-maḥremī kūyıda mạ̣rem bolmaġan

mèndin özgä maḥreminnin maḥremi hem bolmag̉an (İ 25

107: remel: fācilātün fācilātün fācilātün fā‘ilün

veh nėdür èy yār bī-mūcib köyül ḳan ḳılmagạ

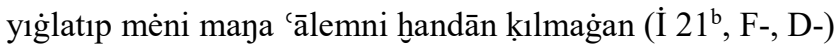

108: remel: fā'ilātün fā'ilātün fā'ilātün fā'ilün

èy közüm sèn-sèn mèni gaam èlkidä zār eylägän

pür neẓāre birle köylümni giriftār eylägän (İ 5

109: remel: fā'ilātün fā'ilātün fã ilātün fā'ilün

èy mėni gurbet diyārıda giriftār eylägän

nāvek-i gaamzen bilän köksümni efgār eylägän (İ-, F 58ª D-)

110: remel: fācilātün fấilātün fā'ilātün fācilün

yār mėnin birle nigārım gāh yahşşı geh yaman

hūb èmäs kim bolsa yārım gāh yahşsı geh yaman (İ 18 b , F-, D-)

111: remel: fe`ilātün fe`ilātün fe`ilātün fe`ilün

kọ̈lüm anı̀ gam-1 hicrān[n1] bile ḳan bolsun

nā-tevān cānım ara hem ġam-ı hicrān bolsun (İ 22a , F-, D-)

112: remel: fā'ilātün fā'ilātün fā'ilātün fā'ilün

èy ki dèr-sèn dehr ara hiç kimgä gurbet bolmasun

bolsa bolsun gurbet ammā derd-i furḳat bolmasun (İ-, F 58

113: remel: fācilātün fācilātün fā'ilātün fā'ilün 
āşinā yārım ki yād ètmäy unutmış yārıdın

gūyiyā bīgāne-veş bolmış vefā ețvārıdın (İ 17º , F-, D-)

114: remel: fā'ilātün fācilātün fā'ilātün fā'ilün

veh yana köylüm ḩaberdār oldı cānān sarıdın

tạ nesīmi gūyiyā èsti Hुorāsān sarıdın (İ-, F 58ª, D-)

115: remel: fā'ilātün fā'ilātün fā'ilātün fā'ilün

tökti köylüm eşk-i ḥırmān dīde-yi maḥrūmıdın

hịç ḩādim tüşmäsün yā Rab yıraḳ maḩūmıdın (İ-, F 58º , D-)

116: remel: fācilātün fācilātün fācilātün fā‘ilün

hatṭ̂ kim ẓāhir boluptur la'l-i nükte-dānıdın

hüccetidür baş körmä dèp haț-1 fermānıdın (İ 27b, F-, D: CXX)

117: remel: fā'ilātün fā'ilātün fā'ilātün fā'ilün

terk-i ‘ālem eylägümdür ehl-i ‘ālem ța'nıdın

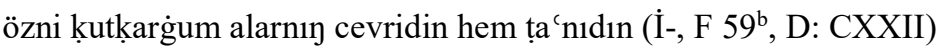

118: remel: fā'ilātün fā'ilātün fā'ilātün fā'ilün

her ḳaçan gülzārg̉a tüşsä güzārım sẻnsizin

bolg̀usıdur āteşīn güllär şerārım sėnsizin (İ 9a , F-, D-)

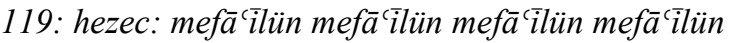

lețâfet bāgiının nev-res nihāl-i gül- 'izāārı-sèn

selāmet bol kim ötkän serv-ḳadlar yādigārı-sèn (İ-, F 59aa , D-)

120: remel: fā'ilātün fā'ilātün fā'ilātün fā'ilün

èy ḳuyaş baştın ayaḳ mundaḳ ki garḳ-ı nūr-sèn

veh melek-sèn yā perī yā ādemī yā hūur-sèn (İ-, F 59º , D: CXIII)

121: remel: fā'ilātün fā'ilātün fầilātün fã'ilün

dil-berimġa ger dèsäm kim sènin uçūn zār-mèn

ol maya dèr kim sènin dèk zārdın bīzār-mèn (İ 11 ${ }^{\mathrm{b}}, \mathrm{F} 58^{\mathrm{b}}, \mathrm{D}$ : CXI)

122: remel: fā'ilātün fācilātün fā'ilātün fā'ilün

ehl-i '1şk evrāḳıda bes kim be-istihkāḳ-mèn 
Two New Manuscript Copies of Shāhī Dīvān / Ü. Aslan (p. 99-126)

yazdılar evvel mėni ser-defter-i 'uşşāḳ-mèn (İ-, F 59ª D-)

123: remel: fā'ilātün fā'ilātün fā'ilātün fã'ilün

çāre istäp yüzigä dėsäm neżāre eyläyin

çūn işim bī-çārelıḳdur veh nè çāre eyläyin (İ 9b, F-, D-)

124: remel: fā'ilātün fā'ilātün fā'ilātün fā'ilün

ger dèsäm bir nev` ile köylümni hursend eyläyin

hūb-rūlardın birävni ana mānend eyläyin (İ 14 $\left.{ }^{\mathrm{b}}, \mathrm{F}-, \mathrm{D}-\right)$

\section{ḥarfü'l-vāv}

125: remel: fācilātün fācilātün fācilātün fācilün

aya nè gam ' $1 s ̧ k$ ile ger bar ise şeydā biräv

yā mėnin dèk bolsa şeydālık bile rüsvā biräv (İ-, F 60ª , D: XXVI)

\section{ḥarfü'l-hā}

126: remel: fā'ilātün fā'ilātün fā'ilātün fā'ilün

‘ārıżı dèk bir güli yoḳtur İrem gülzārıda

kim İrem gülzārıdın dėgäy cemālı barıda (İ-, F 60º , D-)

127: remel: fā'ilātün fā'ilātün fā'ilātün fã'ilün

ḳılmayın mu derd ilän feryād u efg̈ān bu kèce

sènsizin kim cāngadur derd-i firāvān bu kèce (İ-, F 60ª , D: CXXXIII)

128: remel: fā'ilātün fā'ilātün fā'ilātün fā'ilün

tapmadım maḥūmluḳḳa mundın özgä çāreni

kim yıraḳdın ḳılġa-mèn ol kū sarı neẓz̄āreni (İ 4a , F-, D-)

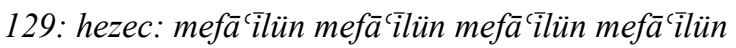

èmästür bāk cismim ' 'ş̧ḳ ara ma'dūm eger bolsa

ma'āża'llāh ki yüzidin közüm maḥrūm eger bolsa (İ 23 a , F-, D-)

130: remel: fā'ilātün fā'ilātün fā'ilātün fā'ilün

dostlar yüz şükr vācibtür mėnin dèk zārġa

kim könül ag̉lap mèn andaḳ nāzenīn dil-dārg̉a (İ 23 ${ }^{\text {b }, ~ F-, ~ D-) ~}$

131: hezec: mefācīlün mefācīiün mefācīlün mefā'cīlün 
sana kim dèdi kim cānā ḥazīn köyülni şād ètme

unutġıl bir yolı bizni vü özgä hịç yād ètme (İ-, F 61ª, D:CXLI)

132: remel: fấ'ilātün fā'ilātün fā́cilātün fā'cilün

èy köyül ol kū sarı bu kün güzzer ḳıldım yana

ḳadd u ruhsārığa toyġunca naẓar ḳıldım yana (İ 8 ${ }^{\text {b }}$, F-, D-)

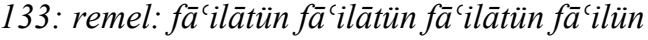

köylüme bī-dād ètär hụ̂r-ı perī-zādım yana

ḳoydı virānlıḳka yüz bu miḥnet-ābādım yana (İ-, F 60 b , D-)

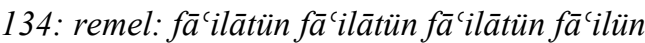

sünbül-i pür-tābığa köylümni bağladım yana

mèni baştın bende ḳ̂ldı serv-i āzādım yana (İ-, F 61ª, D-)

135: remel: fā'ilātün fấcilātün fắcilātün fắcilün

āh u vāveylā éki gül-çihre zārı mẻn yana

nāvek-i müjgānlarınnı̀ dil-figārı mèn yana (İ-, F 60ª , D-)

\section{ḥarfü'l-lām-elif}

136: remel: făcilātün fấcilātün făcilātün fấcilün

başım üzre ol șanem yètti dègünce ayttı lā

eyläbän rence ḳadem yètti dègünce ayttı lā (İ-, F 61 ${ }^{\mathrm{a}}$, D-)

\section{ḥarfü'l-yā}

137: remel: făcilātün fă'ilātün făcilātün fā'iliün

riş bolġan hecridin köksümni ana körsätäy

körsätip ol aynı ḥālımġa zamāni yıġlatay (İ 2b , F-, D-)

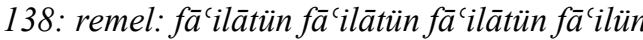

nè refị̣̂i kim gamım köyli ara kār eylägäy

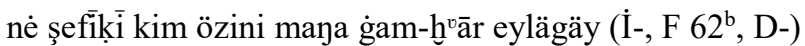

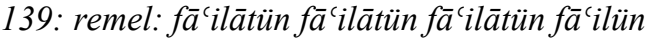

istäräm közdin demī kim yār gāàib bolmaġay

ölgüçe ayrılmasam andın 'acāyib bolmag̉ay (İ $21^{\text {b }}$, F-, D-) 
Two New Manuscript Copies of Shāhī Dīvān / Ü. Aslan (p. 99-126)

140: remel: fā'ilātün fā'ilātün fā'ilātün fā'ilün

körmägil yā Rab revā kim yār ḳadrım bilmägäy

andın ayru kèlsä vaḳtımġa ecel ol kèlmäğäy (İ 11ª F-, D-)

141: remel: fā'ilātün fấcilātün fā'ilātün fā'ilün

nèçe andın èlgä hem-demlıḳ körüp rencūr olay

renc tartıp èl ara bu ḥāl ilä meşhūr olay (İ 29b , yaprak kopmuş, F-, D-)

yār çūn istär sènin vīrānlı̀̇ı köylüm turul

istäsäy kim 'ışḳ terkin eyläbän ma'mūr olay (İ 20ª , yaprak kopmuş, üsteki matlaın devamı olmalı, F-, D-)

142: remel: fā'ilātün fā'ilātün fā'ilātün fā'ilün

nęçe sėnsiz miḥnet ü gam kūyıda menzil ḳılay

miḥnet ü gamnı özümgä kūh bile ḥāṣıl ḳılay (İ 9b , F-, D-)

143: remel: fā'ilātün fā'ilātün fā'ilātün fā'ilün

bāg̀-1 bihiştnin ḳaçan sèn dèk gül-i sìr-ābı bar

kim yüzünnin ėy sehī-ḳad özgä āb u tābı bar (İ 24흐, bir yaprak kopmuş, F-, D-)

144: remel: fācilātün fā'ilātün fā'ilātün fā'ilün

veh ki yètkürdi mèni bī-dilga devrān miḥneti

yār hecri vü vațan terki vü gurbet şiddeti (İ-, F 61 ${ }^{\text {b }}$, D: CXLV)

145: remel: fā'ilātün fā'ilātün fā'ilātün fā'ilün

yètmäs èrdi èy felek cānımġa cānān miḥneti

kim hucūm ètmiş yana başımġa devrān vahş̧eti (İ $3^{\mathrm{b}}, \mathrm{F} 62^{\mathrm{b}}$, D-)

146: remel: fā'ilātün fā'ilātün fā'ilātün fā'ilün

yār bī-pervālığıdın vāy ḳadrim bilmädi

yoḳsa nėçūn bi்-sebeb ḥālımġa pervā ḳılmadı (İ 25a , F-, D-)

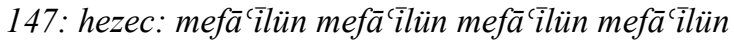

lebim çūn la 'l-i cān-bahşı̀ndın èy cān behrever boldı

tașavvur eylädim gūyā ki aġzım pür-şeker boldı (İ-, F 63ª D-)

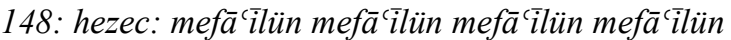

naẓardın barg̉aç ol gül-çihre çihrem za ferān boldı 
temāşā ehli dèrlär kim bahār ötti ḩazān boldı (İ-, F 62a , D-)

149: remel: fā'ilātün fā'ilātün fā'ilātün fã'ilün

ḳanı dey faṣlı kim ol cem iyyet-i aḥbāb èdi

‘ayş u 'işret ḥāżır u endūh u ġam nā-yāb èdi (İ 3 ${ }^{\mathrm{a}}$, F-, D-)

150: remel: fā'ilātün fā'ilātün fā'ilātün fā'ilün

èy köyül bu kėcelärdä hem-nişīnim yār èdi

veh nè dèp aytay nè türlük kim hużūrum bar èdi (İ 7ª F-, D-)

151: remel: fā'ilātün fā'ilātün fā'ilātün fā'ilün

èy köyül ol bī-vefā bir gün maya dil-dār èdi

bolmasa dil-dārlı̣ hod iltifătı bar èdi (İ-, F 63 , D-)

152: remel: fācilātün fācilātün fācilātün fācilün

körgäy èrdim munca gam ger yār eger bolsay èdi

bī-dil olgay mu èdim dil-dār eger bolsay èdi (İ $\left.18^{\mathrm{b}}, \mathrm{F}-, \mathrm{D}-\right)$

153: remel: fā'ilātün fā'ilātün fā'ilātün fā'ilün

èl tilindin çūn bara almas-mèn ol yārım sarı

bārì sèn bar èy köyül cān birle dil-dārım sarı (İ 28 b, F-, D-)

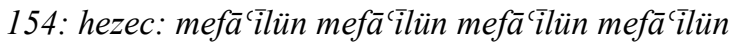

yana olturdı cān bostānıda bir serv-i nev-hīizi

ki bir bir tār-1 zülfi sünbüli bar pür dil-āvīizi (İ 5 $5^{\text {b }, ~ F-, ~ D-) ~}$

155: remel: fā'ilātün fā'ilātün fā'ilātün fācilün

mihri yoḳdın ḳaṣd-1 cān ḳılmaḳdur ol cānān işi

mihr țavrıdın fidā bolmaḳdur ana cān işi (İ-, F 61 ${ }^{\text {b }}$, D: CXLVI)

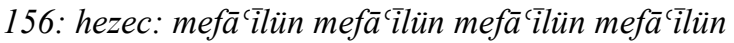

mạa ehl-i riyā evḳātıdın [ėse] şarāb olay

naẓarda sāḳi-yi meh-veş èlikdä cām-1 nāb olay (İ-, F 63º, D-)

157: remel: fā'ilātün fā'ilātün fā'ilātün fā'ilün

yètkürür cevr-i felek köylümgä her laḥẓa gami

āh u vāveylā gamım şerh ètkäli yoḳ mahremì (İ-, F 62a , D-) 
Two New Manuscript Copies of Shāhī Dīvān / Ü. Aslan (p. 99-126)

158: remel: fā'ilātün fā'ilātün fā'ilātün fā'ilün

sāḳiyā tut vaṣl bezmi içre 'işret cāmnı

kim içip mey ḳılmalın yād èmdi hecr eyyāmnı (İ 16 ${ }^{\text {b }}$, F-, D-)

159: remel: fā'ilātün fā'ilātün fā'ilātün fā'ilün

zülfǖä baġlap giriftār-1 belā ḳıldın mèni

köylüm alıp yüz belāga mübtelā ḳıldın mèni (İ-, F 62a , D-)

160: remel: fācilātün fācilātün fācilātün fācilün

saldı hicrān deştidä köp zulm ètip devrān mèni

gerdiş-i çarh eylädi el-ḳıșṣa ser-gerdān mèni (İ-, F 63ª , D-)

- [Yazı silik olduğundan okunamadı] (İ 16 ${ }^{\mathrm{a}}$ )

\section{Rubā iyyāt}

161: Ahreb

Tèjri [...] olsun yārā

'işret daġı hem- inānı̀ olsun yārā (İ 30º , F-, D-)

162: Ahreb

kèlgil ki köyül sèndin èrür miḥnet ilä

yüz derdḳa zār miḥnet-i gurbet ilä (İ 30ª F-, D-)

163: Ahreb

devlet saya müstedām bolsun yā rab

sulțān-1 cihān g̉ulām bolsun yā rab (İ 30a , F-, D-)

164: Ahreb

vașlıy maya müstedām bolsun yā rab

cişret meyi hem be-kām bolsun yā rab (İ 30º , F-, D-)

165: Ahreb

közüyä remed yèli güzār ètti meger

cānım gehī ol közni figār ètti meger (İ 31ª, F-, D-)

166: Ahreb

èy dostlarım men`-i merām eylämäniz 
eylär isäniz velī müdām eylämäniz (İ 31 $1^{\text {b }}$ F-, D-)

167: Ahreb

andın ki tilim gamıyla fersūde èmiş

ol şehr ferāgat ḳlıp āsūde èmiş (İ 31 b , F-, D-)

168: Ahreb

ol kim fütāde köyülgä āzārı anı̣

cān birle köyülgä bar-durur zārı anıı (İ 31 b , F-, D-)

169: Ahreb

kūyun ara kim girip gedālı̣ ḳıldım

‘ālem èli içre hod-nümālıḳ ḳıldım (ì 30 b, F-, D-)

170: Ahreb

cānā tünä kün ki ḩod-nümālı̣ ḳıldım

vaṣlın meyidin tiläp gedālı̣ ḳıldım (İ 31 a, F-, D-)

171: Ahreb

èy yār hemiş̧e Tènri yārın bolsun

ammā bu țaraf gehī güz̄ārın bolsun (İ 30 ${ }^{\mathrm{b}}, \mathrm{F}-$, D-)

172: Ahreb

başı̀ga köyül hemişe şāhıy bolsun

ol şeh keremi sẻnin penāhıy bolsun (İ 31 a, F-, D-)

173: Ahreb

eger ki cüdāllḳ ètse yārım n'ètäyin

andın yana ḳaldı cism-i zārım n'ètäyin (İ 31 b , F-, D-)

174: Ahreb

dèr-mèn ki barıp yüzün temāşā ḳılayın

eyyām-1 vișālınnı temennā ḳılayın (İ 31ª, F-, D: CLXXIX)

175: Ahreb

‘ömrüm keç̧ädür hecr içidä āhım ile

zülfün ġamıdın bu hāall-i vāhım ile (ì 30ª F-, D-) 
Two New Manuscript Copies of Shāhī Dīvān / Ü. Aslan (p. 99-126)

176: Ahreb

bezmi tiläräm ki bolg̀a-mèn yār bile

ol bezm içidä bolmasa deyyār bile (İ 30a , F-, D-)

177: Ahreb

yārım özidin mèni cüdā ḳılsa n’ètäy

hicrān u gam birle mübtelā ḳılsa n'ètäy (İ 30ª F-, D-)

\section{Taḥmīsāt}

178: [Taḥmīs-i Şāhī be-gazel-i Nevāyì)]

remel: fācilātün fācilātün fācilātün fācilün

āh kim köylüm öyini guș̣̦a mesken ḳıldı lā

guuṣṣa naḳdı birle ol vīiānnı maḥzen ḳıldı lā (İ-, F 67a , D-)

179: [Taḥmis-i Şāhì be-ġazel-i Hüseynī]

remel: fā'ilātün fā'ilātün fā'ilātün fā'ilün

'1şḳ derdidin yètişti èrnimä cānım mènin

güllär açdı ḳan yaşımdın ḩār-ı müjgānım mènị (İ-, F 65², D-)

180: [Taḥmīs-i Şāhì be-gazel-i Nevāyī]

remel: fā'ilātün fā'ilātün fācilātün fā'ilün

èy ki cān dèk naḳd-1 ‘ömr-i cāvidānım-sèn mènin

mihr ile ėmdi dėmän kim hem- inānım-sèn mėnin (İ-, F 65ª, D-)

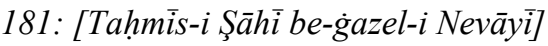

remel: fācilātün fā'ilātün fā'ilātün fā'ilün

gülbün-i nāznınnı țūbādın misāāl aytam hayāl

bilmädim kim țūbì èrmiş serv-i nāzındın mișāl (İ-, F 68ª D-)

182: [Taḥmīis-i Şāhì be-ġazel-i Nevāyī]

remel: fā'ilātün fā'ilātün făcilātün fā'ilün

yār kim vaṣlığa köp èrdim țalebkār èy köjül

barıban yėtkürdi maḥzūn cāng̀a āzār èy köjül (İ-, F 63º , D-)

183: [Taḥmīis-i Şāhi be-ġazel-i Nevāyī]

remel: fā'ilātün fā'ilātün fācilātün fā'ilün 
sèn kılıp ‘azm-1 sefer mèn sèndin ėy cān ḳalmışam

yèrgä yüz sürtüp yoluyda zār u giryān ḳalmışam (İ-, F 68b D-)

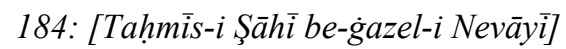

remel: fā'ilātün fā'ilātün fā'ilātün fācilün

vāy yüz min vāy kim derd ü gaam-ı hicrānıdın

'azm ètär çıḳmaḳḳa cān tendin köyül efgāānıdın (İ-, F 64'a D-)

185: [Taḥmīs-i Şāhī be-ġazel-i Nevāyī]

remel: fācilātün fā'ilātün fā'ilātün fācilün

èy sınuk köylümni her dem ḳan ḳılıp devrān kibi

gamzen oḳı tuttı yèr kọ̈lüm içindä cān kibi (İ-, F 69a , D-)

186: [ (Taḥmīs-i Şāhì be-gazel-i Nevāyì)]

remel: fācilātün fā'ilātün fācilātün fācilün

èy köyül 'sşḳ èlgidin mèn zār olup şeydā besī

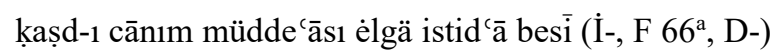

187: [Taḥmiss-i Şāhì be-ġazel-i Hüseyni]

remel: fācilātün fācilātün fācilātün fācilün

ol ki cevr eyläp yıraḳ taşlar vefāsıdın mèni

eylämäs huursend vaṣl-ı cān-fezāsıdın mèni (İ-, F 67º , D-)

\section{Terci '-est-i İnān}

188: Ahreb

hurremlığını ki kūyıdın yètsä șabā

yètkürsä nevīd-i vaṣl u peyġām-1 vefā (İ-, F 69² , D-. Yalnız üç beyit yazılmıştır.)

\section{Sonuç}

Şâhî Dîvânı'nın İ nüshası, şair henüz hayatta iken 895/1489'da istinsah edilmiş olup muhtemelen onun kontrolünden geçmiştir. Bu yazmada 109 şiir mevcuttur. Bunlardan 95’i diğerlerinde yok iken 3’ü F'de ve 7'si D'de de bulunmaktadır. Şiirlerin 4'ü ise bütün nüshalarda vardır. Şiirlerin 84'ü remel bahrinin fācilātün fā'ilātün fācilātün fācilün, 1’i fe'ilātün fecilātün fecilātün fe'ilün; 5’i hezec bahrinin mefācịlün

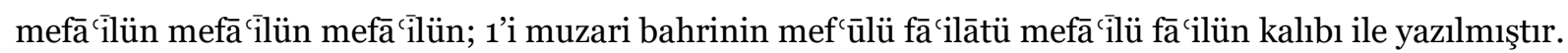
Nüshadaki 17 rubai ise ahreb kalıpları ile kaleme alınmıştır.

Dîvân'ın F nüshası bir mecmua içinde yer almakta olup toplam 86 şiir ihtiva etmektedir. Şiirlerden 57'si yalnız bu yazmada bulunmakta iken 3'ü İ ve 22'si D'de de vardır. 4 şiir ise bütün nüshalarda ortaktır. F’deki şiirlerin 75’i remel bahrinin făcilātün fācilātün fācilātün fā'ilün, 1’i fe'ilātün fecilātün fecilātün 
Two New Manuscript Copies of Shāhī Dīvān / Ü. Aslan (p. 99-126)

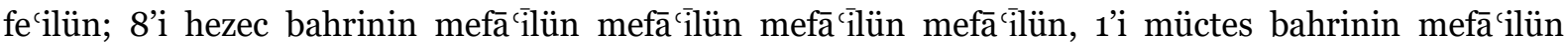
fe 'ilātün mefā'ilün fe'ilün kalıbı ile yazılmıştır. 1 terci'-bendin vezni ise ahrebtir.

Dîvân’’n İngiltere nüshaları ile İ ve F nüshalarını karşılaştırdığımızda şöyle bir sonuç ortaya çıkmaktadır: Yalnız İ nüshasında olan şiir sayısı 95, yalnız F'de bulunan şiir sayısı 57, İ ve F nüshalarında ortak olan şiir sayısı ise 3'tür. Buna göre yalnız İ ve F nüshalarında D'de olmayan 155 yeni şiir yer almaktadır. Sonuçta bu iki nüsha, şiir bakımından Şâhî Dîvânı’na önemli ölçüde katkıda bulunmaktadir.

\section{Kaynakça}

Arat, R. R. (hzl.) (2006). Gazi Zahîreddin Muhammed Babur, Baburnâme (Vekayi). Kabalcı Yayınevi. İstanbul.

Bal, S. (2013). British Museum Turkî Ms 23’te Kayıth Çağatayca Şâhî Divanındaki Gazeller (vr. 1b1ob; Transkripsiyon, Çeviri, Sözlük). Yüksek Lisans Tezi. İstanbul Üniversitesi Sosyal Bilimler Enstitüsü. İstanbul.

Eckmann, J. (2003). Harezm, Kipçak ve Çağatay Türkçesi Üzerine Araştırmalar. Yayıma hzl. Osman Fikri Sertkaya. Türk Dil Kurumu. Ankara.

Eraslan, K. (hzl.) (2001). Alî Şîr Nevâyî, Mecâlisü’n-Nefâyis I (Giriş ve Metin), II (Çeviri ve Notlar), Türk Dil Kurumu, Ankara.

Kılıç, F. (2007)."Şâhî (Mesud Mirza) ve Çağatayca Divanının Bilinmeyen Bir Nüshası”. Edebiyat ve Dil Yazıları Mustafa İsen'e Armağan. ed. Ayşenur Külahlığlu İslam - Süer Eker. s. 389-393.

Lugal, N. (çev.) (2011). Devletşah, Tezkiretü'ş-şu’arâ. Pinhan Yayıncılık. İstanbul.

Mirzaev, T. (2001). Sultan Mes'ud Mirza Şahiy Devan. Ozbekistan Respublikası Fenler Akademiyası Alişer Nevaiy Namidagi Til ve Adabiyat İnstituti. Taşkent.

Tekcan, M. (2005). Mesud Mirza Şâhî Divan. Doğu Kütüphanesi Yayıncılı. İstanbul. 